\title{
Pertanggalan Relatif Situs Gunungwingko (Studi Pendahuluan)
}

\section{Goenadi Nitihaminoto}

Keywords: relative dating; prehistory; settlement; neolithic; java; chronology

\section{How to Cite:}

Nitihaminoto, G. (1989). Pertanggalan Relatif Situs Gunungwingko (Studi Pendahuluan). Berkala Arkeologi, 39-50. https://doi.org/10.30883/jba.v10i1.537

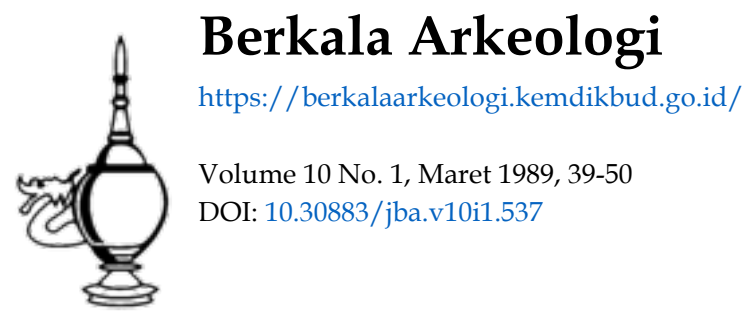




\section{PERTANGGALAN RELATIF SITUS GUNUNGWINGKO (STUDI PENDAHULUAN)}

Oleh :

Goenadi Nitihaminoto

Situs Gunungwingko berupa dua deret bukit pasir. Deretan pertama terletak di sebelah utara, sedangkan deretan kedua terletak di sebelah selatannya. Deretan bukit pasir pertama selanijutnya disebut B1, sedangkan deretan bukit pasir kedua disebut B2. Penelitian di B1 telah dilakukan sebanyak 7 kelompok, yaitu $B 1 \quad A-G$ dan penelitian di B2 telah dilakukan sebanyak 5 kelompok, yaitu B2 Hh.

Kedua deret bukit pasir itu berorientasi barat-timur, sejajar dengan garis pantai, terletak antara 12001500 meter di sebelah utara pantai Samudera Indone-sia, tinggi antara 5-15 meter di atas muka air laut, dan lebarnya antara 100-150 meter (Bemmelen, 1949). Secara administratif situs tersebut termasuk dalam Ke-lurahan Srigading dan Kelurahan Tirtohargo, Kecamatan Sanden, Kabupaten Bantul, yaitu sekitar $30 \mathrm{~km}$ di se-belah selatan Yogyakarta.

B1 mulai diteliti tahun 1972, dengan temuan anta-ra lain berupa gerabah, pecahan tulang manusia dan tulang hewan, pecahan perunggu, pecahan keramik asing, serta manik-manik; sedangkan B2 mulai diteliti tahun 1976, dengan temuan berupa gerabah, keramik asing, dan manik-manik. Sebelum tahun 1972 daerah Gunungwingko telah menarik perhatian para ahli, anta-ra lain van der Hoop, van Bemmelen, dan van Verstap-pen. Baik para ahli yang melakukan peneli tian sebelum maupun sesudah tahun 1972 memberikan pertanggalan relatif yang berbeda-beda, sehingga belum ada kesatuan pendapat, karena ditinjau dari beberapa aspek yang berbeda. Itulah sebabnya dalam kesempatan ini penulis ingin mencoba memberikan gambaran tentang pertang-galan relatif situs Gunungwingko, dengan menyatukan 
hasil analisis aspek temuan yang berbeda tersebut, sehingga diperoleh gambaran yang terpadu.

\section{Beberapa bukti pertanggalan relatif}

Bukti-bukti yang mengacu pada pertanggalan relatif di situs ini antara lain diperoleh dari stratigrafi, gerabah dan hiasannya, artefak perunggu, rangka manusia, dan pecahah keramik asing. Proses pembentukan bukit pasir di daerah ini dan sekitarnya dihubungkan dengan erupsi Gunung Merapi tua, karena mineralmineral pokok yang sama, berupa olivin, augit, hiperstin, dan hornblende (van Verstappen, 1957).

Dalam penelitian stratigrafi selanjutnya diketahui bahwa secara umum bukit pasir itu terdiri atas dua lapis, yaitu lapisan atas dan lapisan bawah. Lapisan atas terbentuk oleh tenaga angin, sehingga berupa bukit pasir; sedangkan lapisan bawah berupa beting gisik (beach ridge) yang terbentuk oleh tenaga gelombang (Sunarto, 1986). Lapisan atas dihubungkan dengan ledakan Gunung Merapi yang terjadi pada 1008 M (van Bemmelem, 1971), sedangkan lapisan beting gisik terbentuk sebelum waktu itu (Sutanto dan Jomulyo, 1973). Pembentukan beting gisik pada B2 diperkirakan terjadi sekitar 800 tahun yang lalu (van de Velde, 1986:324).

Penelitian gerabah di daerah ini didasarkan atas motif hiasan, terutama motif hias anyaman atau tenunan. Ditinjau dari 1apisan tanahnya, gerabah berhias motif anyaman dikatakan, berasal dari budaya neolitik -(van der Hoop, 1938). Kemudian, motif hias gerabah anyaman ini dihubungkan dengan, tradisi bertenun di daerah Sentolo, sehingga diperkirakan motif ini berasal dari 2000 tahun yang lalu, sesuai dengan umur tradisi tersebut (van Stein Callenfels, 1961).

Hias gerabah bermotif anyaman tersebut diterakan pada bagian dasar gerabah berbentuk nyiru (winnow type). Sementara pendapat mengatakan bahwa gerabah ini berasal dari industri pembuatan garam di daerah itu 
yang berasal dari sebelum tahun 1778, meskipun garis pantai yang sekarang ada di sebelah selatan B2 mungkin telah terbentuk sekitar 500-600 tahun yang lalu (van de Velde, 1988: 83).

Sementara itu gerabah berhias tera tatap berpola geometris diberi pertanggalan lebih muda dari pada situs-situs percandian di Prambanan dan Plaosan, yaitu sesudah abad $X$. Selain di situs-situs percandian, hiasan gerabah ini tersebar luas antara lain di pantai selatan Jawa (Goenadi Nitihaminoto, 1984: 30), seperti pantai selatan Trenggalek dan pantai selatan Jember, Jawa Timur. Penyebaran ke arah barat motif hias semacam itu sampai di Kota Cina, yang diperkirakan merupakan situs hunian dari abad.XII-XIV (Sonny Wibisono, 1982 : $13-15)$.

Jenis hiasan gerabah lain adalah hias gosok (streaky) yang ditemukan di B1-E, B1-F, dan B2-H. Gerabah berhias gosok yang ditemukan di B1-E, B1-F, dan B2-H tidak ditemukan persamaannya di sekitar situs Gunungwingko, dan jenis hiasan itu secara melimpah ditemukan di situs-situs percandian, seperti kompleks Candi Prambanan dan Kraton Ratu Baka. Kereweng hias ini disebut Prambanan Red Black Streaky (PRBS) dan berasal dari tahun 1025-1050 M (Teguh Asmar dan Bennet Bronson, 1973 : 52).

Pecahan keramik asing yang ditemukan dari penggalian di B1-A, B1-C, dan B2-J berjumlah 105 keping, dengan rincian dari B1 61 keping dan B2 44 keping. Pecahan keramik asing dari B1 yang berasal dari kedalaman $0-50 \mathrm{~cm}$ berjumlah 60 keping, dengan pertanggalan antara abad $X-X V I I I$, sedangkan yang berasal dari kedalaman $50-100 \mathrm{~cm}$ berjumlah 1 keping, yaitu dari abad XIV (1380). Pecahan keramik asing abad $X-X V I I I$ masing-masing berasal dari dinasti Tang abad $X$ (900) sebanyak 2 keping, Sung XII (1120-1160) sebanyak 11 keping, Sung XIII (1200-1280) 36 keping, Yuan XIII (1270-1290) 2 keping, Yuan XIV (1350- 
1380) 7 keping, Qing XVIII (1750) 1 keping, dan Eropa abad XIX (1890) sebanyak 1 keping.

Pecahan keramik asing dari B2 kedalaman $0-50$ $\mathrm{cm}$ berjumlah 4 keping dan berasal dari antara abad IX-XVI, sedangkan dari kedalaman $50-100 \mathrm{~cm}$ berasal antara abad IX-XVI sejumlah 40 keping. Pecahan keramik asing dari kedalaman $0-50 \mathrm{~cm}$ masing-masing berasal dari Tang abad IX (850) sejumlah 1 keping, Sung abad XIII (1250) 2 keping, dan Yuan abad XIV (1350) 1 keping, sedangkan dari kedalaman $50-100 \mathrm{~cm}$ terdiri atas keramik asing dari dinasti Tang abad IX (850) 17 keping, Lima Dinasti abad $\times$ (950) 5 keping, Thailand abad XII-XIII $(1150-1250) 3$ keping, Sung abad XIII (1250-1280) 11 keping, Yuan abad XIV (1350-1380) 3 keping, dan Ming abad XVI (1540) 1 keping.

Temuan artefak perunggu pada umumnya berupa pecahan dari barang-barang perhiasan, seperti pecahan gelang atau cincin, yang sampai saat ini belum pernah ditemukan bentuk utuhnya. Dari analisis elemental terhadap artefak perunggu dapat diketahui bahwa artefakartefak tersebut mempunyai kandungan Sn tinggi, sehingga jarang ditemukan di situs-situs di luar Indonesia. Kandungan Sn tinggi ini menunjukkan bahwa para undagi telah memiliki tingkat pengetahuan teknologi logam tinggi dan sudah melewati masa eksperimental (Timbul Haryono, 1985: 635). Penggunaan Sn tinggi di Asia Tenggara berlangsung pada masa akhir abad ke-5 SM, sampai menjelang awal Masehi. Dengan demikian situs Gunungwingko diperkirakan berasal dari masa-masa awal Masehi atau sesudah abad ke-5 SM (Timbul Haryono, $1986: 13)$.

Sisa rangka manusia yang ditemukan di Gunungwingko merupakan sisa rangka manusia modern. Secara antropologis, sisa rangka manusia Gunungwingko menunjukkan populasi yang lebih muda bila dibandingkan dengan populasi manusia Gilimanuk dan diduga semasa 
dengan populasi manusia Gunungpiring di Lombok (Koeshardjono, 1987: 56-7), yang diperkirakan berasal dari sekitar abad XII (Goenadi Nitihaminoto, 1980 : 123).

\section{D i s kus i}

Dari uraian di atas dapat diketahui bahwa pertanggalan relatif situs Gunungwingko mempunyai variasi dan bentangan waktu yang cukup besar, yaitu berasal antara awal abad Masehi atau sesudah abad V SM sampai dengan abad $X$. Pertanggalan-pertanggalan tersebut diperoleh dari artefak perunggu yang berasal dari akhir abad V SM atau masa awal Masehi, dari gerabah dan hiasannya yang berasal dari 2000 tahun yang lalu sampai sebelum tahun 1778, dari stratigrafi yang berasal dari awal abad XI (1006), dari rangka manusia diperkiirakan berasal dari abad XII, serta dari keramik asing berasal dari abad IX (850) sampai akhir abad XIX (1890).

Di antara bukti-bukti pertanggalan di atas, yang lebih dapat dipercaya adalah dari stratigrafi, keramik asing, hiasan gerabah, dan kerangka manusia. Temuantemuan itu tampaknya mengandung nilai pertanggalan relatif yang hampir bersamaan atau berurutan, sehingga perlu dijadikan titik tolak dalam penentuan pertanggalan relatif situs ini.

Stratigrafi. Dalam proses pembentukan bukit pasir, B1 berbentuk lebih dahulu dari B2, sehingga B1 lebih tua dari pada B2. Apabila ternyata benar bahwa lapisan bukit pasir di B1 terbeñtuk pada sekitar tahun 1006, maka lapisan beting gisik terbentuk pada masa sebelum itu. Dengan demikian pada abad XI mungkin belum ada aktivitas, karena bukit pasir itu sedang dalam proses pembentukan. Oleh karena itu, kegiatan masa lampau di B1 mungkin baru terjadi paling cepat pada awal XII. Sementara itu di B2 mungkin sedang terjadi proses pembentukan beting gisik, dan lapisan bukit pasir mungkin baru terbentuk pada abad XII itu juga. 
Keramik asing. Keramik asing dari B1 yang berasal dari kedalaman $0-50 \mathrm{~cm}$ terdiri atas abad $\times 2$ keping, abad XII 11 keping, abad XIII 38 keping, abad XIV 7 keping, abad XVIII dan XIX masing-masing 1 keping, sedangkan dari kedalaman $50-100 \mathrm{~cm}$ berasal dari abad XIV 1 keping. Keramik asing dari B2 yang berasal dari kedalaman $0-50 \mathrm{~cm}$ terdiri dari abad IX 1 keping, abad XIII 2 keping, dan abad XIV 1 keping, sedangkan dari kedalaman $50-100 \mathrm{~cm}$ yang berasal dari abad IX berjumlah 17 keping, abad $\times 5$ keping, abad $\times$ II 3 keping, abad XIII 11 keping, abad XIV 3 keping, dan abad XVI 1 keping.

Dari data pertanggalan tersebut di atas yang perlu dicatat dari $\mathrm{B} 1 \mathrm{0}-50 \mathrm{~cm}$ adalah bahwa temuan terbanyak berasal dari abad XIII, abad XII, dan abad XIV, sedangkan dari kedalaman $50-100 \mathrm{~cm}$ hanya 1 keping dari abad XIV. Keramik asing B2 $50-100 \mathrm{~cm}$ terdiri dari 17 keping abad IX, 11 keping abad XIII, 5 keping dari abad $X$, dan masing-masing 3 keping dari abad XII-XIII dan XIV.

Bila dilihat pecahan keramik asing terbanyak berasal dari B1 $0-50 \mathrm{~cm}$ mulai dari abad XII, abad XIII, dan abad XIV, dan dari kedalaman $50-100 \mathrm{~cm}$ berasal dari abad XIV yang jumlahnya hanya 1 keping. Berdasarkan kenyataan itu, dapat dikatakan bahwa lapisan tanah di tempat penelitian telah terganggu, sehingga temuan yang berumur lebih muda terletak di bagian bawah. Selain itu dapat pula dikatakan bahwa kegiatan di B1 mungkin terjadi mulai abad XII, abad XIII, dan abad $X I V$. Kegiatan ini tidak terjadi pada abad $X$, karena keramik asing dari abad yang lebih tua dapat disimpan pada masa-masa yang lebih muda sebagai barang pusaka (Teguh Asmar dkk., 1975: 70).

Lapisan tanah B2 juga telah teraduk, karena sama dengan keadaan di B1, terbukti dari temuan keramik asing yang berumur muda terdapat di lapisan bawah, sedangkan keramik asing yang tua di lapisan atas. Ber- 
dasarkan temuan keramik asing ini diperkirakan kegiatan di B2 terjadi pada abad XIII.

Hiasan gerabah. Motif gosok (streaky) dan motif geometris. Hiasan gerabah motif gosok ditemukan di B1-E dan F serta B2-H. Motif hiasan ini dapat ditemukan di beberapa situs percandian terdekat, seperti Prambanan dan Kraton Ratu Baka, yang berdasarkan hasil penelitian berasal dari pertengahan abad XI dan dikenal sebagai Prambanan Red Black Streaky (Teguh Asmar dan Bennet Bronson, 1973: 52). Oleh karena gerabah hias gosok tersebut ditemukan di situs-situs percandian, maka selain berfungsi sebagai wadah upacara, gerabah hias gosok pemakaiannya masih terbatas di kalangan situs-situs 'percandian saja. Apabila pernyataan itu benar, maka gerabah hias gosok ini dipakai oleh masyarakat umum dalam upacara di luar situs percandian tentu setelah masa itu. Pemakaian hiasan gosok dikenal oleh masyarakat Gunungwingko kemungkinan baru di sekitar abad XII.

Gerabah hias tera tatap selalu ditafsirkan sebagai suatu petunjuk dari masa yang sangat awal. Akan tetapi berdasarkan kenyataan, gerabah berhias tera berbalut tali masih berlangsung terus hingga saat ini di beberapa tempat di Sumatera (Bennet Bronson dkk., 1973: 31). Dari pernyataan itu maka gerabah berhias tatap motif geometris di B2 mungkin berumur lebih muda dari pada gerabah hias gosok.

Dari segi teknologinya memang hias tera tatap ini lebih rumit, sehingga tidak mudah ditiru karena memerlukan ketrampilan khusus. Dengan demikian maka hias pola geometris ini ke luar dari lingkungan percandian lebih belakangan dari pada hias gosok. Dari hal itu dapat diperkirakan bahwa jenis hiasan ini mulai dipakai di Gunungwingko mungkin akhir abad XII atau awal abad XIII, yaitu sesudah hias gosok diterima oleh masyarakat Gunungwingko pada masa lampau. 
Kerangka manusia. Kerangka manusia yang ditemukan di B1-C mempunyai persamaan-persamaan dengan manusia Gunungpiring, yaitu persamaan ras dan budaya. Persamaan budaya dapat dijumpai dengan adanya mutilasi pada gigi dan persamaan gerabah tertentu, antara lain kendi gogok. Oleh karena itu manusia Gunungwingko mungkin berasal dari abad XII seperti halnya manusia Gunungpiring.

\section{Beberapa Pendapat}

Berdasarkan penelitian geologis terbukti B1 mulai terbentuk sekitar abad XI. Kegiatan manusia di B1 ini mungkin mulai terjadi sekitar awal abad XII. Hal ini didukung oleh temuan rangka manusia yang ada di B1 tersebut, yang berasal dari abad XII. Dari uraian itu dapat diperkirakan bahwa kegiatan manusia di B1 mula-mula terjadi di kelompok C dan B, karena antara C dan $B$ mempunyai persamaan temuan yang menonjol. Tampaknya kegiatan di B1 ini berlangsung terus sampai abad XIII dan XIV.

Kegiatan yang mula-mula terjadi di B1-B dan C, kemudian pada abad XII itu terjadi kegiatan lagi di B1-E dan $F$, dan kegiatan selanjutnya terjadi di B1-A pada abad XIII dan abad XIV, sementara itu kegiatan di B1-B dan C masih tetap berlangsung.

Kegiatan selanjutnya beralih ke B2, tetapi aktivitas di B1 masih berlangsung. Kegiatan di B2 mula-mula terjadi di kelompok $H$ sebagai kelanjutan aktivitas dari $B 1-E$ dan $F$, yang mungkin terjadi pada akhir abad XII atau awal abad $X I I I$. Kegiatan ini berlangsung terus meluas ke arah barat yang di B2-J terjadi antara abad XIII atau abad XIV.

Pada aktivitas-aktivitas itu kedua bukit pasir ini belum dihuni oleh masyarakat Gunungwingko, karena bukit pasir memang kurang memberikan kenyamanan hunian. Penghunian di kedua bukit pasir ini mungkin terjadi sebelum tahun 1778. Penghunian pertama dila- 
kukan oleh beberapa orang yang membuat pondok-pondok sementara untuk berteduh dalam pembuatan garam, seperti yang terjadi di desa Ngentak Bakalan yang terletak beberapa kilometer di sebelah barat situs Gunungwingko.

Lama kelamaan pondok-pondok sementara tempat berteduh itu berubah menjadi tempat tinggal. Lebihlebih setelah pembuatan garam dilarang oleh Pemerintah Belanda tahun 1778, sebagian besar penghuninya kembali ke desa di sebelah utaranya dan sebagian lagi tetap tinggal di bukit pasir tersebut (Sunarjo, 1983: 25-27). Demikian selanjutnya sehingga penghunian di kedua bukit pasir itu berlangsung sampai saat ini. 


\section{KEPUSTAKAAN}

Bemmelen, R.W. van, 1949. The Geology of Indonesia Vol. la. General Geology. The Hague, Martinus Nijhoff.

Bemmelen, R.W. van, 1970 Four Volcanic Outbursts that Influence Human History Toba, Sunda, Merapi and Thera. The First International Scientific Congress on Volcano of Thera. Athena.

Bronson, Bennet, et al, 1973, Laporan Penelitian Arkeologi di Sumatra. LPPN-The University of Pennsylvania Museum.

Callenfels, P.V. van Stein, 1961, Pedoman Singkat Koleksi Prasejarah Museum Pusat Lembaga Kebudayaan Indonesia. Proyek Rehabilitasi dan Perluasan Museum DKI Jakarta.

Nitihaminoto, Goenadi, 1980, Ekskavasi Gunung Piring (Lombok Tengah Selatan) 1976. PIA I.

Nitihaminoto, Goenadi, 1984 "Decorated Pottery from the South Coast of Java between Pacitan and Cilacap". Studies on Ceramic. Pusat Penelitian Arkeologi Nasional, Jakarta.

Hoop, A.N.J. Th. a Th. van der, 1938, "De Praehistorie". Geschiedenis van Nederlandach Indie. Deel I. Amsterdam.

Koeshardjono. (1987). SISA RANGKA MANUSIA DARI SITUS GUNUNG WINGKO. Berkala Arkeologi, 8(2), 47-57. https:// doi.org/10.30883/jba.v8i2.492

Sonny Wibisono, 1982, "Tembikar Kota Cina : Sebuah Analisis Pendahuluan". Amerta 6.

Sunarjo, 1987, "Masyarakat Ngentak Bakalan (Studi Kekerabatan hubungannya dengan Transmigrasi)". Thesis Sarjana pada Jurusan Antropologi Fakultas Sastra UGM.

Sunarto. (1986). PENDEKATAN PEDOGEOMORFOLOGI DALAM PENELITIAN ARKEOLOGI DI GUNUNG LANANG DAN GUNUNG WINGKO (BANTUL). Berkala Arkeologi, 7(1), 27-38. https://doi.org/10.30883/jba.v7i1.449 
Soetanto BR, S. dan Jomulyo, 1973, "Stratigrafi Daerah Gunungwingko". Fakultas Geografi UGM. Belum diterbitkan.

Teguh Asmar dan Bennet Bronson, 1973, Laporan Ekskavasi Ratu Baka. Lembaga Purbakala dan Peninggalan Nasional - The University of Pennsylvania Museum.

Timbul Haryono, 1985, "Analisis Elemental Benda-benda Perunggu Situs Gunungwingko: Evaluasi Metalurgi". REHPA II. Pusat Penelitian Arkeologi Nasional, Jakarta.

Timbul Haryono, 1986 "Beberapa Artefak Perunggu Situs Gunung Wingko, Catatan tentang Aspek-aspek Teknologis". PIA IV.

Velde, Pieter van de, 1986 "Our The 1985 Excavation at Gunungwingko: A Preliminary Account". PIA IV.

Velde, Pieter van de, 1988, "On an Early Salt Industry on Java's South Coast". Time Past, Time Future Perspective on Indonesian Culture, VKI 131.

Verstappen, H. Th., 1957, "Short Note on the Dunes near Parangtritis (Java). Tijdschrift van het Koninklijk Nederlandsch Aardrijkskundig Genootachap. Deel LXXIV No. 1. 


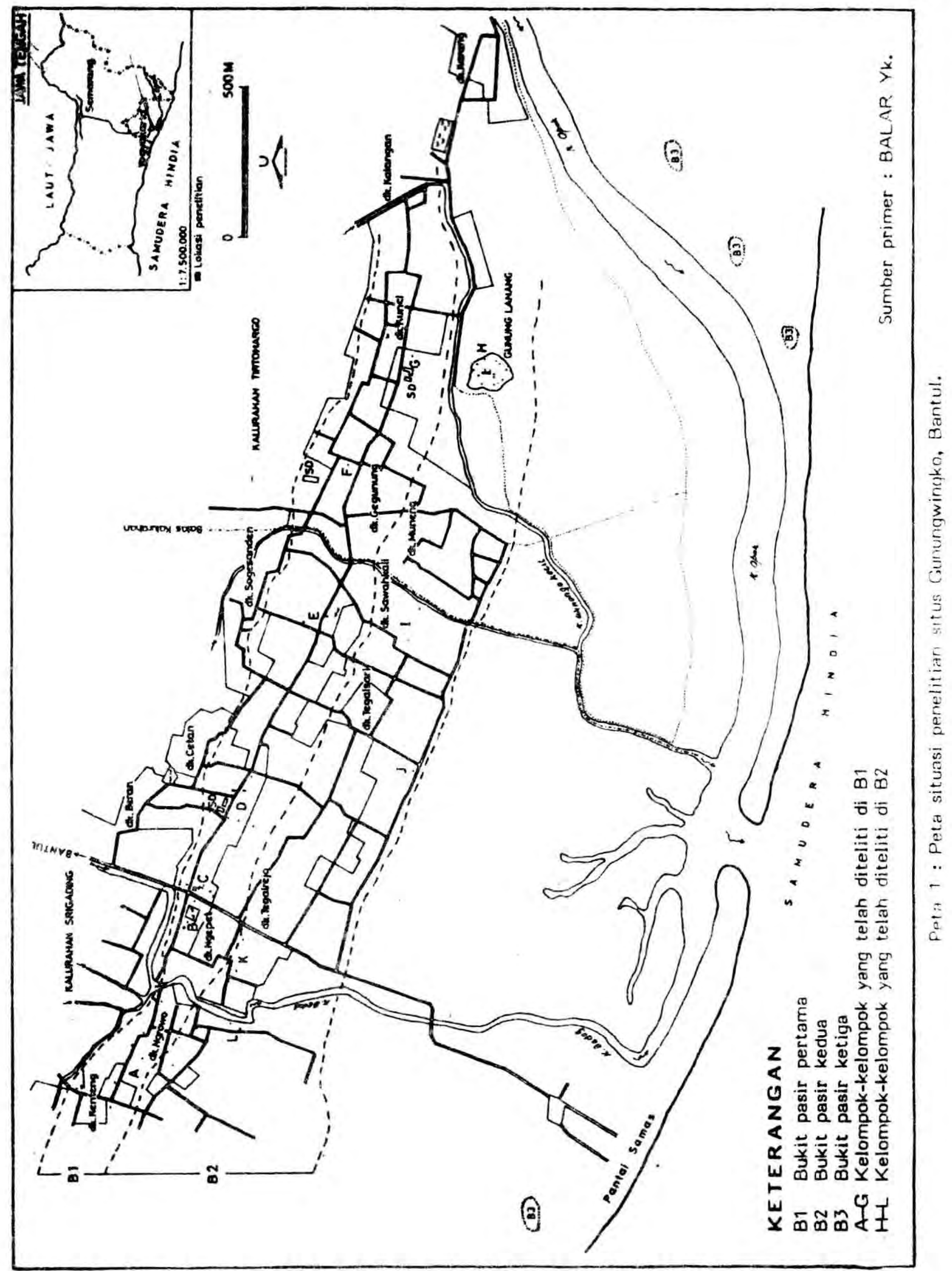

